\title{
Visualization of The Procoagulant Effects of Combined Oral Contraceptives (COCs)
}

\author{
Kluft $\mathrm{C}^{* 1}$, Naji $\mathrm{S}^{1}$, Talens $\mathrm{S}^{1}$, Jespersen $\mathrm{J}^{2}$ and Ataullakhanov $\mathrm{F}^{3}$ \\ ${ }^{1}$ Good Biomarker Sciences, Netherlands \\ ${ }^{2}$ University of Southern Denmark, Campus Esbjerg, Denmark \\ ${ }^{3}$ Center for Theoretical Problems of Physicochemical Pharmacology, Russia
}

Submission: July 05, 2018; Published: August 24, 2018

*Corresponding author: Kluft C, Good Biomarker Sciences, Zernikedreef 8, 2333CL Leiden, Netherlands, Tel: +31 653622221; Email: kluft@kluft.in

Keywords: Oral contraceptives; Thrombosis risk; Haemostatic factors; Venous thrombotic embolism; Laboratory analysis; Global clotting assay; Inhibitory potential; APC-resistance test; Coagulation activation potential; Clotting tests; COC-use; Ethinyloestradiol; Desogestrel; Procoagulant effects; In-vitro analysis; VTE risk; Pharmacodynamic method; Thrombin formation

Abbreviations: COC: Combined Oral Contraceptives; VTE: Venous Thrombotic Embolism; APC: Activated Protein C

\section{Introduction}

It is well established that the use of oral contraceptives increases the risk of venous thromboembolism. Attempts to understand the underlying mechanisms has resulted in documentation of changes in many specific haemostatic factors. The changes related to the thrombosis risk have not been established and prevented validated evaluation of new COCs for thrombosis risk before exposing large groups of women and evaluating clinical effects, i.e. venous thrombotic embolism (VTE) [1].

An obvious approach of laboratory analysis would have been to use global haemostatic assays. It has been documented that the global clotting assay APTT becomes shorter compatible with an increased potency of the system to clot, and thereby disclose an increased coagulation activating potential. However, this variable is not robust, and changes are small [2]. Another global coagulation test for the inhibitory potential of coagulation inhibition, the APC-resistance test, was more successfully applied and showed a reduced inhibition potential during COC-use [3]. APC-resistance, therefore has been considered one of the beacons in evaluation of VTE risk of COCs. A test for thrombin formation showed between 18 and $31 \%$ increases [4-6]; this test reveals thrombin formation during the presence of the clot.

Recently, a new pharmacodynamic method for coagulation activation potential has been developed. Unlike previous global clotting tests, this test evaluated the increase (volume) of the fibrin clot. This was a lacuna in in-vitro analysis of humans, while frequently employed in experimental thrombosis models in animals.

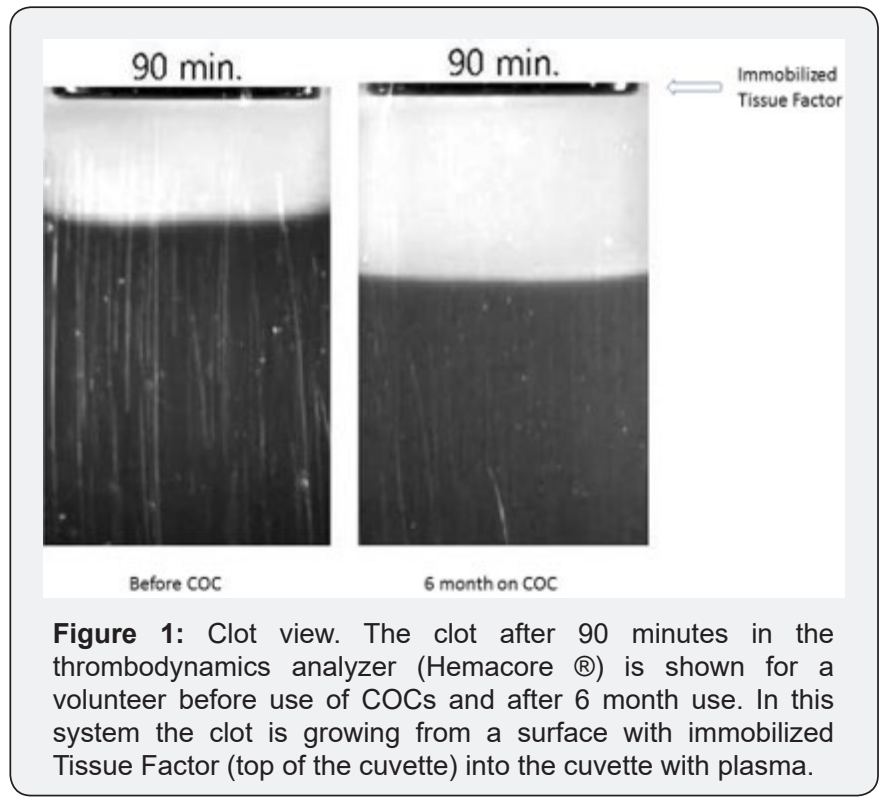

In Figure 1, it can be clearly seen that after a fixed period the clot during COC-use is larger.

\section{Results}

We tested the growth in 10 apparently healthy young women (age 18-35y) with the same regimen of 6 month use of a third generation COC of $30 \mu \mathrm{g}$ Ethinyloestradiol/150 $\mu \mathrm{g}$ Desogestrel, from a larger study [7]. The size of the clot after 5000 seconds was on average (median) 27\% (range 14-46\%) larger during COC- 
use. The growth rate at 5000 seconds, showed for the individuals in Figure 2, was more clearly increased with an median of $71 \%$ (range 59-143\%). Next to the increases a substantial range in effect can be seen. The values of clot size and growth rate during COC-use were for 5 of the 10 cases above the highest pretreatment value of the small study sample.

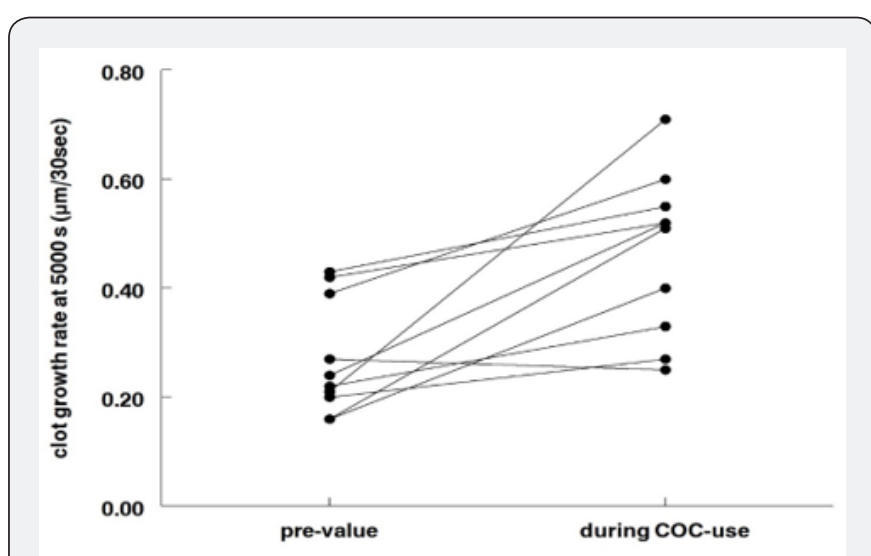

Figure 2: Individual changes in clot growth rate at time point 5000 secs (in $\mu \mathrm{m} / 30 \mathrm{sec}$ ) for 10 women from before the start and to after 6 months of COC-use.

\section{Conclusion}

This method to assess coagulation activity potential, expressed in clot size and growth rate, might be a valuable beacon together with the global inhibitor test to evaluate effects of COC in small groups and characterize old and new oral contraceptives.
A next step of validation would be to test the combination of clot size/growth and APC-resistance in several cohorts with different contraceptives where the VTE risk is known.

\section{References}

1. Reid RL, Westhoff C, Mansour D, de Vries C, Verhaeghe J, et al. (2010) Oral Contraceptives and Venous Thromboembolism Consensus Opinion from an International Workshop held in Berlin, Germany in December 2009. J Fam Plann Reprod Health Care 36(3): 117-122.

2. Rosing J, Tans G, Nicolaes GA, Thomassen MC, van Oerle R, et al. (1997) Oral contraceptives and venous thrombosis: different sensitivities to activated protein $\mathrm{C}$ in women using second- and third-generation oral contraceptives. Br J Haematol 97(1): 233-238.

3. Stocco B, Fumagalli HF, Franceschini SA, Martinez EZ, MarzocchiMachado CM, et al. (2015) Comparative study of the effects of combined oral contraceptives in hemostatic variables: an observational preliminary study. Medicine (Baltimore) 94(4): e385.

4. Rotteveel RC, Roozendaal KJ, Eijsman L, Hemker HC (1993) The influence of oral contraceptives on the time- integral of thrombin generation (thrombin potential) Thromb Haemost 70(6): 959-962.

5. Westhoff CL, Pike MC, Cremers S, Eisenberger A, Thomassen S, et al. (2017) Endogenous thrombin potential changes during the first cycle of oral contraceptive use. Contraception 95(5): 456-463.

6. Zia A, Callaghan MU, Callaghan JH, Sawni A, Bartlett H, et al. (2015) Hypercoagulability in adolescent girls on oral contraceptives-global coagulation profile and estrogen receptor polymorphisms. Am J Hematol 90(8): 725-731.

7. Seven pill study (2003) The effects of seven monophasic oral contraceptive regimens on hemostatic variables: conclusions from a large randomized multicenter study. Contraception 67(3): 173-185.

Your next submission with Juniper Publishers
will reach you the below assets
- Quality Editorial service
- Swift Peer Review
- Reprints availability
- E-prints Service
- Manuscript Podcast for convenient understanding
- Global attainment for your research
- Manuscript accessibility in different formats
( Pdf, E-pub, Full Text, Audio)
- Unceasing customer service
Track the below URL for one-step submission
https://juniperpublishers.com/online-submission.php

